\title{
Saudi EFL Teaching Training Programmes: Teachers' Perceptions and Needs
}

\author{
Fatimah Oudah \\ College of Education, King Saud University, Saudi Arabia \\ Sultan Altalhab \\ College of Education, King Saud University, Saudi Arabia
}

\begin{abstract}
This study explores Saudi EFL teachers' needs and perceptions towards training programmes in Saudi Arabia. The data were collected using a semi-structured questionnaire from a total of 215 EFL teachers; 10 of these teachers were also interviewed. The main findings revealed that Saudi EFL teachers have a positive attitude and view that training programmes meet their various needs, such as a need for programmes on English teaching aids; assessment and grading strategies concerning learners' language proficiency; and programmes concerning classroom practices that implement activities to support language acquisition and development. On the other hand, the teachers showed a need for training programmes on teaching English at the primary school level, plus for training programmes with qualified and professional trainers and educators. The study concludes with some implications and recommendations based on the findings.
\end{abstract}

Index Terms - teacher education, training programmes, perceptions, needs

\section{INTRODUCTION}

Teaching and preparing future teachers is fundamental for the success of the whole teaching process, leading to the successful implementation of future generations that are skillful, educated, and cultural. Freeman and Johnson (2001) define teacher education as 'the notion that teachers can be equipped in advance, at the start of their careers, for all that they will need to know and be able to do throughout their teaching lives' (p. 55). A milestone for any curriculum development success is the effective training of the teachers, which is based on programme evaluation. This is the main step in the professionalisation of English language teachers (Coskun \& Daloglu, 2010).

Teachers' professional learning is a complex process which requires emotional and cognitive involvement, whether individually or in groups with other teachers (Avalos, 2011). Therefore, teacher education programmes can be challenging, calling for new solutions to prepare the teachers to fulfil their students' needs (Zeichner, Payne \& Brayko, 2014). Research concerning teacher education is quite limited and lacking in focus (Grenfell, 2014). It is noteworthy that 'the more competent teachers feel, the more successfully they teach' (Gándara, Maxwell-Jolly \& Driscoll, 2005, p. 12). Teachers' willingness to develop their practices in class is common but the methods of how to do so needs to be investigated. EFL teacher training programmes support teachers in many areas, but further investigation is needed to ascertain whether these programmes actually match teachers' needs (Hüttner, Mehlmauer-Larcher, Reichl, \& Schiftner, 2011).

Many of the systematic reforms currently taking place in the Saudi context are necessary to maintain the enormous shift in all fields of study and curricula developments. Reforms are progressing to compensate for the defects of the past, with English language teaching taking on large-scale importance regarding changes to textbooks and the practice of new theories of language teaching. Teachers' education and training are of core significance in all these transitions. Saudi Colleges of Education offer courses covering eight semesters in order to prepare students to become EFL teachers.

Additionally, practical training is considered an important part of a teacher preparation programme. Berry (1990) argues that teachers' training influences their teaching and raises their proficiency level. Nevertheless, there are many in-service teacher training problems; some, as Bayrakci, (2009) indicates, include a lack of professional staff, lack of collaborative partnerships between teachers, lack of provision for feedback and lack of systematic in-service training models. In the Saudi context, teacher preparation programmes are 'non-systematic' and 'inadequate'; therefore, there is a call for more improvement to EFL teacher education programmes, encouraging them to take a systematic approach to pre- and in-service education (Al-Hazmi, 2003, p. 341).

Teachers' development and training are essential for raising levels of student proficiency. Recent studies in English language teaching methodologies have shown that teachers who stay up to date with the latest teaching techniques are always efficient (Farooq, 2016). Therefore, teachers are required to hold various qualifications in order to gain highlevel knowledge and pedagogy, which will enhance their professional development (Alsalahi, 2015). Reasons behind the low language proficiency of school students in English language communication skills include aspects such as the educational system itself, teacher training, and the methods used in classrooms (Alharbi, 2015). 
To date, a considerable body of research has sought to understand teachers' perceptions of training programmes and training needs. This research aims to provide a number of important insights, especially with regard to EFL teachers' training needs. In particular, it is noted that research on determining EFL teachers' perceptions towards training programmes in relation to their training needs in Saudi Arabia is lacking. This study is conceptually intriguing because it bridges two important domains in modern research (i.e., teachers' perceptions and training needs) that are likely related but seldom intermingled. This research seeks to fill this gap by quantitatively and qualitatively examining teachers' needs and perceptions of programmes that are scheduled, yearly, for the training of Saudi English teachers.

\section{TeAChers' Professional DeVElopMEnT}

Teacher PD is defined as 'teachers learning, learning how to learn, and transforming their knowledge into practice for the benefit of their students' growth' (Avalos, 2011, p. 10). Teachers are thus no longer to be considered as solely implementing theory in order to practice, but active mediators and constructors of knowledge (Hüttner et al., 2011). Guskey (2002) describes PD programmes as systematic attempts to bring about changes in teachers' practices, attitudes and beliefs, and the learning outcomes of students.

There is evidence that PD can lead to improvements in instructional practices and student learning. Furthermore, it may increase teachers' use of certain practices in the classroom such as active learning opportunities (Desimone, Porter, Garet, Yoon \& Birman, 2002). Tong, Luo, Irby, Lara-Alecio and Rivera (2017) investigated the direct impact of an intensive and structured PD programme on teachers' time allocation and Spanish-speaking English language learners' development. The results of the treatment group show the effectiveness of a PD programme on teachers' practice, in terms of time allotment and learners' language outcomes. Another study by Karimi (2011) on the potential of PD in enhancing teachers' beliefs about their teaching ability shows that the group receiving three 16-session courses obtained significantly higher efficacy scores than did the control group.

Most PD programmes are particularly designed to enrich teachers' content and pedagogical knowledge with little concern for the effectiveness and quality of PD endeavors (Guskey, 2003). Many factors could contribute to EFL teachers' PD. According to Amin and Saukah (2016), both personal and environmental factors are highly effective in developing teacher practices such as early interest and early exposure to the English language, as well as environmental aspects like the supervisory system. Consequently, teachers engage in PD programmes because they want to become better teachers (Guskey, 2002). However, 'much of what is termed "professional development" develops no one' (Cole, 2004, p. 3).

\section{Challenges in EFL TEACHer EduCATion}

A number of challenges were identified as being encountered in EFL teacher education according to several studies (e.g. Canh, 2002; Almuhammadi, 2017). Canh (2002) introduces challenges related to EFL teacher training in Vietnam. These include: a gap between training content and the reality of teachers' practices; concentrating on theoretical knowledge; and excluding continuing PD. Similarly, Rhoton and Stiles (2002) denote that most teacher development programmes implemented in schools today, are designed to increase teachers' knowledge more than develop their practices and attitudes. As Almuhammadi (2017) presents, the current PD literature focuses on the process rather than the content or context. However, there needs to be a focus on all three components together: content, context and process. Content is the generic knowledge that is provided in PD programmes; context is the environment where PD takes place; and, finally, process is how these PD programmes are presented.

There are some challenges that result in unsuccessful PD programmes. On the one hand, there is a lack of understanding relating to the knowledge that teachers require from the courses they take part in. This incomplete conception seems to affect educators' practices and goals whilst teaching teachers. On the other hand, the learning environment might generate teachers' conceptual changes. This could provoke the notion of changing teachers' beliefs and, consequently, the practices that they might conduct in class. Further, these factors might restrict the stream of development that teacher educators aim to carry out (Grierson, 2010). Accordingly, there is a need for teacher educators to be qualified.

In the Saudi context, teacher preparation programmes are described as 'non-systematic' and 'inadequate'; therefore, there is a call for more improvement of EFL teacher education programmes with a systematic approach to pre- and inservice education (Al-Hazmi, 2003, p. 341). Consequently, this affects learners' language proficiency and language performance. Several studies have been conducted to present the factors that contribute to EFL PD in relation to personal changes in practices, attitudes and beliefs, and learners' outcomes. Some studies suggest more concern with pre-service and in-service training programmes in the Saudi context, as EFL teachers graduating from colleges of education only undertake a training course that lasts for 60 hours across 15 weeks. This course includes teaching methodologies, after which these methods are practiced in school during the aforementioned period of time. Therefore, the proficiency level of most Saudi English teachers is considered to be of a low level. Thus there is a need for training in-service teachers and setting up plans and programmes for pre-service teachers in the future (Al-Seghayer, 2011).

Although preparation programmes work ahead to prepare and train EFL teachers, it seems that there is no evidence of developing national standards and guidelines to prepare and train Saudi English teachers in the future (Al-Seghayer, 
2011). The majority of students who join English departments or EFL reaching programmes at most Saudi colleges are not proficient in English; therefore, they start their teaching careers with minimal preparation. Additionally, many current teachers graduated from programmes at colleges of language and translation or English literature, taking neither language teaching courses nor practical course (Al-Seghayer, 2017).

\section{SOLUTIONS}

There are some factors that might contribute to enhancing teacher PD; for instance, the focus on professional learning rather than PD. Additionally, the best place to practice learning is the school itself; school leaders need to take more responsibility for building up a professional learning culture within the school, as such a culture creates a team-work environment (Cole, 2004). In particular, many studies have been conducted that explore reflective practices for teachers and are concerned with teaching through teacher development groups. Furthermore, developing teacher educators might affect teachers' PD. Teachers' conceptual changes regarding teaching English could also be substantial.

Reflective teaching is associated with critical self-examination including self-inquiry and self-evaluation (Richards \& Lockhart, 1994). Language teaching can be transformed by looking for the best method that teachers could use to explore and develop their own teaching. This might be achieved by reflective teaching and action research (Richards, 2002). Being reflective can provide teachers with rich opportunities to develop into professional educators. In addition, they may come to construct a self-image of who are they and, in terms of professional role identity, what they do (Farrell, 1999). Mede's (2010) study investigates the impact of collaborative reflection on EFL teachers, revealing that collaborative reflection seems to have a positive effect on EFL teachers' instructional practice and heightens teacher dialogue. Furthermore, Ferdowsi and Afghari (2015) investigate the possible effect of reflective teaching on different aspects of teaching, with results that show the majority of participants emphasising the effect of reflective practice on their communication patterns in the classroom. It also influences classroom management, error correction, techniques and strategies, as well as PD. As reflective practice seems to enhance teachers' ability to develop into professional educators, teacher educators might need to develop, too.

There are few studies related to the PD of teacher educators' professional experiences (Bates, Swennen, \& Jones 2011; Murray \& Male, 2005). Therefore, there are some complexities involved in the role of teacher educators when they try to determine their priorities in promoting their own PD (Bates, et al., 2010). Williams and Ritter (2010) argue that 'there is an assumption that competent, experienced school teachers will automatically become teacher educators' (p. 77). Lunenberg, Korthagen and Swennen (2007) refer to the gap between both the core knowledge of teacher education and the real practices experienced by many teacher educators.

Koster, Brekelmans, Korthagen and Wubbels (2005) demonstrate that some particular quality requirements are needed for teacher educators. For instance, profession and professional profile being made up of task profile and competences profile. Related to task profile, educators can provide teacher education, take part in policy development or carry out research. On the other hand, the competences profile could include teacher educator aspects of knowledge and skills. These profiles may underpin the development of teacher educators and teacher education institutions, which could then lead to improvement in the quality of teacher education. Lunenberg et al. (2007) discuss the consequences for teacher education and show that modelling by teacher educators could increase in changing the views and practices of teachers. The conceptual change about teaching is a factor that might contribute to teacher development.

A longitudinal study by Borg (2011) explores the effect of an intensive eight-week in-service teacher education programme in the UK, concerning the beliefs of six English language teachers. The teachers underwent several experiences in order to enable them to think more explicitly, give voice to their beliefs and focus on ways of developing classroom practices, which reflected these beliefs. The results showed the positive impact of in-service teacher education on the language teachers' beliefs.

Conversely, Mattheoudakis (2007), conducting another longitudinal study, aimed to investigate pre-service EFL teacher beliefs about learning and teaching in Greece. Here, the results showed that student teachers' engagement in teaching practice seems to have a limited impact on the development of their beliefs. The dynamic interactions between teachers' beliefs contributed to a rise in the dialectical relationship between beliefs and practice and revealed the diversity of teachers' belief systems (Zheng, 2013). Therefore, there appears to be a need for further investigation into how teacher training contributes to a teacher's conceptual change regarding EFL teaching.

Another study by Rajab (2013) explores teacher instructional practices within EFL secondary school classrooms in Syria. This study highlights the need to invest in teachers' PD, particularly during the critical phase of curriculum alteration. Similarly, teachers in Saudi Arabia need more training in the following: teaching methods, teaching the four skills, classroom management, teaching grammar, utilising teaching aids, and technology (Al-Harbi, 2006). In particular, there is a need for more teacher training programmes. For example, programmes about how to implement activities that support language acquisition and development in addition to useful teaching materials and tools. Equally important is the emergence of using smartphone apps in classroom activities.

\section{RESEARCH QUESTIONS}

The study aims to investigate the following questions: 
1. What do Saudi EFL teachers expect to obtain from participating in training programmes?

2. To what extent do these training programmes match teachers' needs?

\section{METHODOLOGY}

The population consisted of a number of in-service EFL Saudi male and female public school teachers. Ten EFL teachers (two males and eight females) participated in a semi-structured interview. Also, 216 EFL teachers participated in a semi-structured questionnaire. All the teachers had attended training programmes related to English language teaching, and all were experienced, having taught English for more than one year.

Data analysis

The data of the study were both quantitative and qualitative. The qualitative data were collected using the closed questions employed in the questionnaire. These data were statistically analysed using the computer software programme SPSS in order to provide important information (e.g. frequencies, means and percentages).

All interviews were transcribed fully and revised by repeated listening to the recordings. A thematic approach was adopted to coding in order to increase the reliability of the analysis. The initial stage in the analysis consisted of reading the transcripts several times in order to determine the main themes and categories. The transcripts were coded line by line, to help develop the categories which were related to the themes. The categories were drawn from the data, and informed by the research questions.

\section{RESULTS AND DISCUSSION}

\section{A. Teachers' Expectations and Challenges}

The analysis of teachers' answers to the questionnaire showed the expectations of the participating teachers regarding participation in training programmes. Table 1 shows the mean percentage for each expectation.

TABLE 1.

SAUDI EFL TEACHERS' EXPECTATIONS REGARDING PARTICIPATION IN TRAINING PROGRAMMES

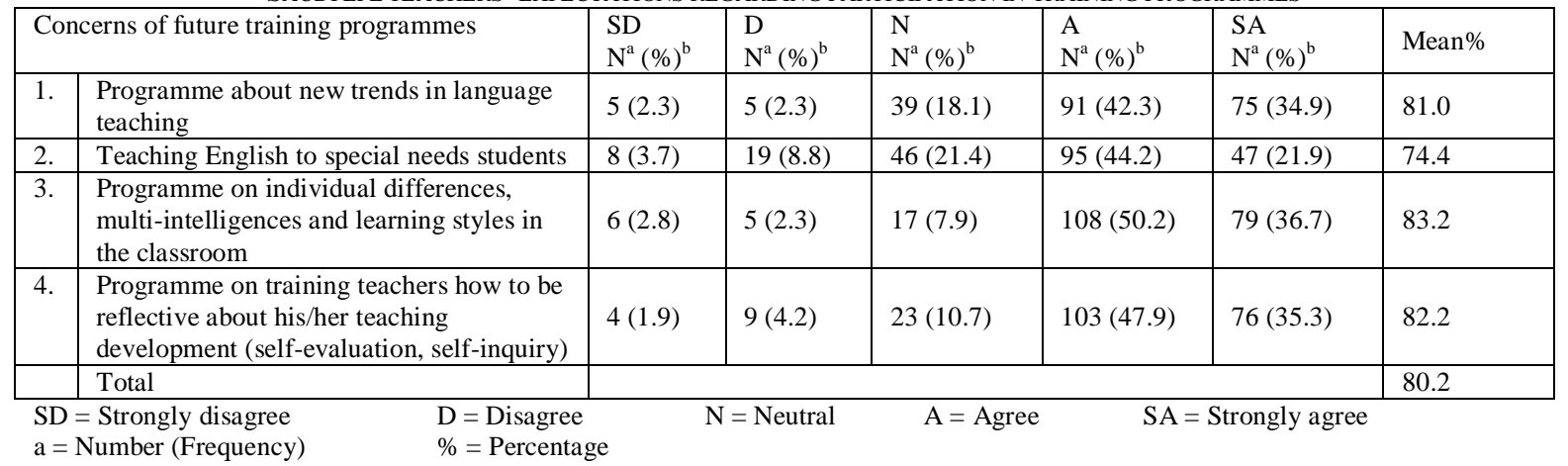

The table shows that $81 \%$ of teachers expected to attend programmes about new trends in language teaching. Also, $74.4 \%$ expected to receive training about teaching English for special needs students while $83.2 \%$ expected to receive programmes on individual differences, multi-intelligences and learning styles in the classroom.

Meanwhile, other studies reveal that English language teachers in Saudi Arabia are in need of more training in the discipline of teaching methods in order to improve their skills and abilities, classroom management techniques, ability to teach grammar, utilisation of teaching aids, and technology (Al-Harbi, 2006). This is consistent with data obtained from the participants during their interview when all participants agreed with the need for such courses, especially in terms of assessing the language level of students. Also, all the participants mentioned being in need of programmes to help them learn more about using teaching aids in language instruction. The majority of the participants expressed a need for programmes that help them better teach students the English language.

Based on the above, it is clear that EFL teachers have the intention to improve themselves, wishing to gain better skills and insights to match the current trends in teaching the English language. In relation to the students, this requirement is congruent with the results revealed by Núñez and Téllez (2009), indicating that all English teachers in elementary schools should be well trained in the scheme of language in order to do their job professionally. The results obtained from the interviews support these findings, with one participant pointing out that she needs programmes about how to demonstrate EFL learners' needs, especially in the primary and intermediate schools. The current study results are stimulating policy-makers in educational schemes and other researchers to improve English language teachers' abilities and skills in relation to several areas such as assessment, teaching methods, language instruction etc.

The results revealed $83.2 \%$ of the teachers expected to receive programmes on individual differences, multiintelligences, and learning styles in class; however, these results are not consistent with the results of Rhoton, and Stiles (2002), which show that most teachers' development programmes are to increase teachers' knowledge more than develop their practices. 
Also, the majority of participants in the current study expressed in the interviews that they are expecting self and PD from the programmes; this resonates with Al-Hazmi (2003) who reveals a need for more improvement in EFL teachers' education programmes, with a systematic approach to pre- and in-service education. Additionally, most of the participants in this study expressed that their training programmes match their classroom teaching practices. This fits with the results of Martinez Agudo (2017) who reveals a relative agreement and satisfaction with the EFL programme, something that, to a certain extent, meets the needs and expectations of teachers.

There are some factors that might contribute to help teachers explore and develop their own teaching. This might be achieved by reflective teaching and action research (Richards, 2002). The current study revealed that $82.2 \%$ of English teachers expect to receive programmes on training teachers how to be reflective about their teaching development. This result could be attributed to the fact that teachers, especially of the English language, need training sessions about reflective educational skills. These results are supported by the qualitative part of this study, where one participant in the study expressed his wishes in terms of a need for reflective skills in education.

On the other hand, the theory-practice gap issue is a significant one in the current literature. The educational sciences take up a big share of this gap, with Lunenberg et al. (2007) concluding that there is a gap between both the teachers' core knowledge of education and the real practices among many educators. Thus, there is a need to have qualified teachers apply what has been taught at the university level in current practical situations like the classroom; furthermore, this was also revealed by Grierson (2010). These results are complementary to the results obtained from the interviews, where some participants expressed that they are not well qualified due to being taught by unqualified and/or nonprofessional trainers and educators.

Another factor that may play a significant role in developing a gap between theory and practice is the behaviour of the educator inside the classroom, which, in turn, leads to the production of students (the teachers of the future). As revealed in the current study results, they are unable to apply evidence-based science to the real world of practice. Some participants expressed this issue as "trainer using lecturing without communication or practicing". Other participants looked at this issue from another point of view, for example, providing expressions and wishes regarding training programmes to be conducted by professional native EFL trainers. This could be attributed to the fact that native EFL trainers have distinctive communication skills during the process of training since the mother tongue language may play an important role.

\section{B. Practical Needs of EFL Teachers}

Regarding the extent to which training programmes match teachers' needs for programmes to evaluate learners' language, table 2 shows the following: $87.2 \%$ of English teachers think that the training programmes match their need to evaluate learners' language fluency, while $85.4 \%$ of them think that the training programmes match their need to evaluate learners' language accuracy.

TABLE 2.

EXTENT TO WHICH TRAINING PROGRAMMES MATCH TEACHERS' NEEDS TO EVALUATE LEARNERS LANGUAGE

\begin{tabular}{|c|c|c|c|c|c|c|c|}
\hline \multicolumn{2}{|r|}{$\begin{array}{l}\text { Need for programme to evaluate learners' } \\
\text { language }\end{array}$} & $\begin{array}{l}\mathrm{SD} \\
\mathrm{N}^{\mathrm{a}}(\%)^{\mathrm{b}}\end{array}$ & $\begin{array}{l}\mathrm{D} \\
\mathrm{N}^{\mathrm{a}}(\%)^{\mathrm{b}}\end{array}$ & $\begin{array}{l}\mathrm{N} \\
\mathrm{N}^{\mathrm{a}}(\%)^{\mathrm{b}}\end{array}$ & $\begin{array}{l}\mathrm{A} \\
\mathrm{N}^{\mathrm{a}}(\%)^{\mathrm{b}}\end{array}$ & $\begin{array}{l}\mathrm{SA} \\
\mathrm{N}^{\mathrm{a}}(\%)^{\mathrm{b}}\end{array}$ & Mean\% \\
\hline 1. & $\begin{array}{l}\text { Fluency (able to speak very well, smoothly } \\
\text { and confidently, with no mistakes) }\end{array}$ & $2(0.9)$ & $2(0.9)$ & $22(10.2)$ & 79 (36.7) & $110(51.2)$ & 87.2 \\
\hline 2. & $\begin{array}{l}\text { Accuracy (being true, correct, or exact and } \\
\text { free from error) }\end{array}$ & $0(0.0)$ & $4(1.9)$ & $24(11.2)$ & $98(45.6)$ & $89(41.4)$ & 85.4 \\
\hline 3. & Learners' needs & $0(0.0)$ & $4(1.9)$ & $25(11.6)$ & $92(42.8)$ & $94(43.7)$ & 85.6 \\
\hline \multirow[t]{2}{*}{4.} & Level and language development & $0(0.0)$ & $2(0.9)$ & $25(11.6)$ & $95(44.2)$ & $9(43.3)$ & 86.0 \\
\hline & Total & & & & & & 86.05 \\
\hline
\end{tabular}

$$
\mathrm{a}=\text { Number (Frequency) } \quad \%=\text { Percentage }
$$

Also, table 2 shows that $85.6 \%$ of English teachers think that the training programmes match their need for programmes to evaluate learner's needs, while $86.0 \%$ think that the training programmes match their need for programmes to evaluate learner's level and language development.

With reference to teachers' expectations of the training programmes in relation to meeting their practical needs, table 3 indicates the extent to which training programmes do match teachers' practical needs.

TABLE 3.

EXTENT TO WHICH TRAINING PROGRAMMES MATCH TEACHERS' PRACTICAL NEEDS

\begin{tabular}{|c|c|c|c|c|c|c|c|}
\hline \multicolumn{2}{|c|}{ Practicum } & \multirow{2}{*}{$\begin{array}{l}\mathrm{SD} \\
\mathrm{N}^{\mathrm{a}}(\%)^{\mathrm{b}} \\
0(0.0)\end{array}$} & \multirow{2}{*}{$\begin{array}{l}\mathrm{D} \\
\mathrm{N}^{\mathrm{a}}(\%)^{\mathrm{b}} \\
1(0.5)\end{array}$} & \multirow{2}{*}{$\begin{array}{l}\mathrm{N} \\
\mathrm{N}^{\mathrm{a}}(\%)^{\mathrm{b}} \\
23(10.7)\end{array}$} & \multirow{2}{*}{$\begin{array}{l}\mathrm{A} \\
\mathrm{N}^{\mathrm{a}}(\%)^{\mathrm{b}} \\
95(44.2)\end{array}$} & \multirow{2}{*}{$\begin{array}{l}\text { SA } \\
\mathrm{N}^{\mathrm{a}}(\%)^{\mathrm{b}} \\
96(44.7)\end{array}$} & \multirow{2}{*}{$\begin{array}{l}\text { Mean\% } \\
86.6\end{array}$} \\
\hline 1. & $\begin{array}{l}\text { English activities which support language } \\
\text { acquisition and development }\end{array}$ & & & & & & \\
\hline \multirow[t]{2}{*}{3.} & Applying applications to classroom activities & $4(1.9)$ & $5(2.3)$ & $31(14.4)$ & $64(29.8)$ & $111(51.6)$ & 85.4 \\
\hline & Total & & & & & & 85.8 \\
\hline
\end{tabular}


$86.6 \%$ of the study participants agree that training programmes do enhance their practical need to teaching English activities which support language acquisition and learners' language development. Also, 85.6\% are in agreement that these programmes increase the usefulness of teaching materials and how to use these in the classroom. These results are consistent with the results of the study by Samson and Collins (2012) who revealed that the understanding of common patterns and milestones of second language acquisition and choice of materials and activities could advocate for teachers' development. Also, since teachers need to be involved in the choice of materials and be included in workshops on how to use multimedia resources and apply them in educational activities (Richards, 2001), they also need to implement and apply these resources to classroom activities.

The study of Hüttner et al. (2011) points out that teachers' willingness to develop their practices in class is common, but methods for how to develop these teaching practices need more clarification. In the current study, all ten EFL teachers in the interviews showed great motivation for attending training programmes in order to develop their skills in a professional manner. Also, most of the participants stated that they optionally attended training programmes, meaning that they had the internal motivation to attend training sessions, confirming a high level of interest in improving their proficiency level. The current study results suggest that good teachers are motivated to develop new skills, improve their abilities, and become proficient in terms of language skills. This resonates with the study by Pinsk, Monson \& Irby (1998), which uncovered that the supposition of language proficiency development is that teachers can develop. The motivation of EFL Saudi teachers shows their willingness to improve and make changes to their skills and language level in order to understand new trends in English teaching. Furthermore, in their interviews, the majority of participants expressed a need for new programmes in order to better teach students the English language.

Moreover, $85.4 \%$ of teachers in the current study agreed that the training programmes match their practical needs in using apps in classroom activities. This is supported by the results obtained from the qualitative section in which five participants expressed their need to attend programmes to help them implement apps in teaching. The use of technology in teaching methods and in the assessment of students is a new trend, one which matches the behavioural requirements of students in the digital age who are familiar with new technology. Thus, as they become familiar with the English language, they may not face so many difficulties in understanding some of the language related issues. This is consistent with the results of Burns (2011), which reveals that mobile technologies offer an alternative way to involve teachers and students in the teaching and learning process. Also, the use of technology in education may enable English language teachers to better be in touch with the students, in terms of understanding learners' preferences, needs and motivations (Kukulska-Hulme, 2013).

\section{CONCLUSION AND IMPLICATIONS}

The study aimed at determining Saudi EFL teachers' needs and perceptions towards training programmes held at training centres in Saudi Arabia, in relation to their training needs. The study adopted a mixed design approach, in which both quantitative and qualitative methods were used to achieve the study objectives. This study stressed the actual needs of the EFL teachers. It might also contain an effective implication concerning the teachers themselves Based on the study findings, some relevant recommendations were suggested, these include several important issues in subsequent training programmes such as new trends in language teaching and training in teaching English to special needs students.

The results obtained from the current study present an optimistic view of Saudi EFL teachers towards the programmes that are scheduled annually at the training centres of the Ministry of Education in Saudi Arabia. In addition, some needs related to teachers in this study indicate that the teachers have a high motivation in terms of improving their abilities and skills in the process of education; consequently, this should make the learning process more familiar, accessible and easier for the students. Additionally, there is a need for more use of technology in educational programmes that occur within the classroom, for example, in activities and assessment strategies. Moreover, English language teachers appear to be looking forward to attending programmes provided by more qualified educators and trainers and learning more about reflective skills in teaching. It is important that training programmes consider the time element and teachers' social and personal issues. Lastly, the findings of this study have discovered many issues that show the perceptions of Saudi EFL teachers towards training programmes; such issues are related to Saudi EFL teachers' future concerns regarding training programmes, and the need for support to be better EFL teachers.

\section{REFERENCES}

[1] Alharbi, H. A. (2015). Improving students' English speaking proficiency in Saudi public schools. International Journal of Instruction, 8(1), 105-116.

[2] Al-Hazmi, S. (2003). EFL teacher preparation programmes in Saudi Arabia: Trends and challenges. TESOL Quarterly, 37(2), 341-344.

[3] Almuhammadi, A. (2017). EFL professional development: Discussion of effective models in literature. English Language Teaching, 10(6), 118-127.

[4] Alsalahi, S. M. (2015). Stages of teacher's professionalism: How are English language teachers engaged? Theory and Practice in Language Studies, 5(4), 671-678.

[5] Al-Seghayer, K. (2011). English teaching in Saudi Arabia: Status, issues, and challenges. Riyadh: Hala Print CO. 
[6] Al-Seghayer, K. (2017). Reality and challenges of TEFL in 21st-Century Saudi Arabia. Riyadh: Hala Print CO.

[7] Amin, M., \& Saukah, A. (2016). Factors contributing to EFL teachers' professional development in Indonesia. Excellence in Higher Education, 6(1), 12-20.

[8] Avalos, B. (2011). Teacher professional development in teaching and teacher education over ten years. Teaching and teacher education, 27(1), 10-20.

[9] Bates, T., Swennen, A., Jones K. (2011). The professional development of teacher educators. London: Routledge.

[10] Bayrakci, M. (2009). In-service teacher training in Japan and Turkey: A comparative analysis of institutions and practices. Australian Journal of Teacher Education, 34(1), 10-22.

[11] Berry, R. (1990). The role of language improvement in in-service teacher training: Killing two birds with one stone. System, 18(1), 97-105.

[12] Borg, S. (2011). The impact of in-service teacher education on language teachers' beliefs. System, 39(3), 370-380.

[13] Burns, M. (2011). Distance education for teacher training: Modes, models and methods. Washington: Education Development Centre Inc.

[14] Cole, P. (2004). Professional development: A great way to avoid change. Melbourne: IARTV.

[15] Coskun, A., \& Daloglu, A. (2010). Evaluating an English language teacher education programme through Peacock's model. Australian Journal of Teacher Education, 35(6), 24-42.

[16] Desimone, L. M., Porter, A. C., Garet, M. S., Yoon, K. S., \& Birman, B. F. (2002). Effects of professional development on teachers' instruction: Results from a three-year longitudinal study. Educational Evaluation and Policy Analysis, 24(2), 81-112.

[17] Farooq, M. U. (2016). Developing teachers' expertise to teach English language: An evaluative study of professional development programme at Taif University English Language Centre. Theory and Practice in Language Studies, 6(2), 274-282.

[18] Farrell, T. S. C. (1999). Reflective practice in an EFL teacher development group. System, 27(2), 157-172.

[19] Ferdowsi, M., \& Afghari, A. (2015). The effects of reflective teaching on teachers' performance. International Journal of Educational Investigations, 2(6), 20-31.

[20] Gándara, P., Maxwell-Jolly, J., \& Driscoll, A. (2005). Listening to teachers of English language learners: A survey of California teachers' challenges, experiences, and professional development needs. Santa Cruz, CA: Center for the Future of Teaching and Learning.

[21] Grenfell, M. (2014). Modern language teacher education. The Language Learning Journal, 42(3), 239-241.

[22] Grierson, A. (2010). Changing conceptions of effective teacher education: The journey of a novice teacher educator. Studying Teacher Education, 6(1), 3-15.

[23] Guskey, T. R. (2002). Professional development and teacher change. Teachers and teaching, 8(3), 381-391.

[24] Hüttner, D. J., Mehlmauer-Larcher, B., Reichl, S., \& Schiftner, B. (2011). Theory and practice in EFL teacher education: Bridging the gap. (1st ed.). Bristol: Multilingual Matters.

[25] Johnson, K. E., \& Freeman, D. (2001). Teacher learning in second language teacher education: A socially-situated perspective. Revista Brasileira De Linguística Aplicada, 1(1), 53-69.

[26] Karimi, M. N. (2011). The effects of professional development initiatives on EFL teachers' degree of self-efficacy. Australian Journal of Teacher Education, 36(6), 50-62.

[27] Koster, B., Brekelmans, M., Korthagen, F., \& Wubbels, T. (2005). Quality requirements for teacher educators. Teaching and Teacher Education, 21(2), 157-176.

[28] Kukulska-Hulme A. (2013). Mobile-assisted language learning. In C., Chapelle (Ed.), The encyclopedia of applied linguistics (pp. 3701-3709). Chichester: Blackwell.

[29] Lunenberg, M., Korthagen, F., \& Swennen, A. (2007). The teacher educator as a role model. Teaching and Teacher Education, 23(5), 586-601.

[30] Martinez Agudo, J. (2017). What EFL student teachers think about their professional preparation: Evaluation of an English language teacher education programme in Spain. Australian Journal of Teacher Education, 42(8), 62-76.

[31] Mattheoudakis, M. (2007). Tracking changes in pre-service EFL teacher beliefs in Greece: A longitudinal study. Teaching and teacher education, 23(8), 1272-1288.

[32] Mede, E. (2010). The Effects of collaborative reflection on EFL teaching. Procedia-Social and Behavioral Sciences, 2(2), 3888-3891.

[33] Núñez, A., \& Téllez, M. (2009). ELT materials: The key to fostering effective teaching and learning settings. Profile Issues in Teachers Professional Development, 11(2), 171-186.

[34] Pinsky, L. E., Monson, D., \& Irby, D. M. (1998). How excellent teachers are made: Reflecting on success to improve teaching. Advances in Health Sciences Education, 3(3), 207-215.

[35] Rajab, T. (2013). Developing whole-class interactive teaching: Meeting the training needs of Syrian EFL secondary school teachers. Unpublished Doctoral Thesis, University of York, York.

[36] Richards, J. C., \& Lockhart, C. (1994). Reflective teaching in second language classrooms. Cambridge: Cambridge University Press.

[37] Richards C. (2001). Curriculum development in language teaching. New York: Cambridge University Press.

[38] Richards, J. C. (2002). 30 years of TEFL/TESL: A Personal reflection. RELC journal, 33(2), 1-35.

[39] Rhoton, J., \& Stiles, K. E. (2002). Exploring the professional development design process: Bringing an abstract framework into practice. Science Educator, 11(1), 1-57.

[40] Samson, J. F., \& Collins, B. A. (2012). Preparing all teachers to meet the needs of English language learners: Applying research to policy and practice for teacher effectiveness. System, 39(3), 370-380.

[41] Tong, F., Luo, W., Irby, B. J., Lara-Alecio, R., \& Rivera, H. (2017). Investigating the impact of professional development on teachers' instructional time and English learners' language development: A multilevel cross-classified approach. International Journal of Bilingual Education and Bilingualism, 20(3), 292-313.

[42] Williams, J., \& Ritter, J. K. (2010). Constructing new professional identities through self-study: From teacher to teacher educator. Professional Development in Education, 36(1), 77-92. 
[43] Zeichner, K. P. KA, \& Brayko, K. (2014). Democratizing teacher education. Journal of Teacher Education, 66(2), 122-135.

[44] Zheng, H. (2013). The dynamic interactive relationship between Chinese secondary school EFL teacher teachers' beliefs and practice. The Language Learning Journal, 41(2), 192-204.

Fatimah Oudah is an EFL teacher in Saudi Arabia. She holds an MA in TESOL from King Saud University. She is interested in EFL teacher education. Email: 43204514@ksu.student.edu.sa

Sultan Altalhab is an Assistant Professor at College of Education at King Saud University in Saudi Arabia. He is interested in teacher education and vocabulary research. He teaches undergraduate and postgraduate TESOL courses and supervises postgraduate research projects. Email: saltalhab@ ksu.edu.sa 